\title{
"The Jews love numbers": Steven L. Anderson, Christian Conspiracists, and the Spiritual Dimensions of Holocaust Denial
}

Matthew H. Brittingham

Emory University

Follow this and additional works at: https://digitalcommons.usf.edu/gsp

\section{Recommended Citation}

Brittingham, Matthew H. (2020) "'The Jews love numbers": Steven L. Anderson, Christian Conspiracists, and the Spiritual Dimensions of Holocaust Denial," Genocide Studies and Prevention: An International Journal: Vol. 14: Iss. 2: 44-64.

DOI:

https://doi.org/10.5038/1911-9933.14.2.1721

Available at: https://digitalcommons.usf.edu/gsp/vol14/iss2/6

This Articles is brought to you for free and open access by the Open Access Journals at Digital Commons @ University of South Florida. It has been accepted for inclusion in Genocide Studies and Prevention: An International Journal by an authorized editor of Digital Commons @ University of South Florida. For more information, please contact digitalcommons@usf.edu. 


\section{"The Jews love numbers": Steven L. Anderson, Christian Conspiracists, and the Spiritual Dimensions of Holocaust Denial}

\section{Acknowledgements}

I would like to thank Dr. Eric Goldstein, Dr. William Allington, Dr. Deborah Lipstadt, Holocaust Denial on Trial (HDOT), and the Tam Institute for Jewish Studies at Emory University for their support and encouragement. I would also like to thank Dr. John Cox and the Center for Holocaust, Genocide, \& Human Rights Studies at the University of North Carolina-Charlotte for allowing me the opportunity to present a previous iteration of this paper at their 2019 conference, "Denial: The Final Stage of Genocide."

\section{Erratum}

Footnotes omitted in original publication are available for download in Supplemental Content. 


\title{
"The Jews love numbers": Steven L. Anderson, Christian Conspiracists, and the Spiritual Dimensions of Holocaust Denial
}

\author{
Matthew H. Brittingham \\ Emory University \\ Atlanta, Georgia, USA
}

From a once largely unknown preacher with a YouTube channel, Steven Anderson's media presence has grown sizably in less than a decade. From his pulpit at Faithful Word Baptist Church in Tempe, Arizona (Independent Fundamental Baptist, or IFB), his vitriolic preaching on religious and social issues has garnered public attention. On a local area news broadcast, Anderson went on record saying that the state should execute homosexuals. ${ }^{1}$ He also gained national notoriety by praying for the death of President Barack Obama. ${ }^{2}$ Praying for the death of a president is a far cry from how many conservative Christians usually, at least in theory, discuss prayer for those in authority, namely praying for the well-being of their leaders or praying that their leaders would follow God's commands. ${ }^{3}$ He was even featured in a BBC mini-documentary that covered his daily life and ministry, entitled "America's Hate-Preachers." ${ }^{4}$ Interest in Anderson's YouTube videos has grown in part due to increased production quality. Paul Wittenberger, owner of Framing the World, a small-time film production company, joined Anderson's cause sometime in the last decade.

Steven Anderson is a conspiracist who is also a fundamentalist Christian. He melds his post-tribulation premillennialism with conspiracies about the United Nations, the 9/11 attacks, translations of the Bible, the Masonic Lodge, and more. ${ }^{5}$ In recent years, Anderson has shown an increased interest in talking about the relationship between Christianity, Judaism, and the State of Israel, culminating in a film entitled Marching to Zion (2015). In this film, Anderson, who firmly embraces replacement theology, also known as supersessionism, championed a wide range of antisemitic stereotypes. ${ }^{6}$ Marching to Zion did not substantively address the Holocaust, however. Whether simply curious about his thoughts or as a counterpoint to his claims, Anderson's viewers brought up the Holocaust, and Anderson felt compelled to share his views. The preacher produced a nearly 40-minute video, "Did the Holocaust Really Happen?,"7 in which he espoused what Deborah Lipstadt has called "hardcore" Holocaust denial, "den[ying] the facts of the Holocaust" in an "outright and forceful fashion." ${ }^{8}$ Though his "scientific" evidence for the "Holocaust

${ }^{1}$ USA Today, "Pastor Defends His Anti-homosexual Sermon," interview by Mark Curtis, December 6, 2014, YouTube video, 5:33, accessed July 30, 2019, https://www.youtube.com/watch?v=UbSM kxpObc.

${ }^{2}$ Rob Boston, "Pastor Of Hate: When Religious Right Rhetoric Goes Too Far," Wall of Separation (blog), Americans United for Separation of Church and State, September 2, 2009, accessed March 1, 2020, https://www.au.org/blogs/wall-ofseparation/pastor-of-hate-when-religious-right-rhetoric-goes-too-far.

${ }^{3}$ Conservative Christians in the United States often cite 1 Timothy 2:1-7 as the biblical approach to those in authority. However, several conservative Christian pastors were quite open in praying for the death of President Obama; see, Lilly Fowler, "Praying for Obama's Death," Salon, November 24, 2009, accessed July 30, 2019, https://www.salon. com/2009/11/24/praying for obama death/.

${ }^{4}$ See the BBC documentary, originally televised October 11, 2016, on YouTube: BBC, "America's 'Hate' Preacher: Pastor Steven Anderson-BBC Documentary," YouTube video, 23:29, accessed July 30, 2019, https://www.youtube.com/ watch?v=K4PvxG2Kh4E; also see Hannah Livingston, “'Hell's Gonna be Pretty Hot for you': My Summer with a Christian Hate Preacher," BBC, July 24, 2017, accessed July 30, 2019, https://www.bbc.co.uk/bbcthree/article/2e465c60cdd3-48f5-8944-e9b2786e3ce9. The IFB has experienced some recent controversy, see Sarah Smith, "Hundreds of Sex Abuse Allegations Found in Fundamental Baptist Churches Across U.S.," Fort Worth Star-Telegram, December 9, 2018, accessed July 30, 2019, https://www.star-telegram.com/entertainment/living/religion/article222576310.html; Alexander Kacala, “Anti-gay Pastor Resigns After Allegedly 'Being With Prostitutes'," NBC News, January 7, 2019, accessed July 30, 2019, https://www.nbcnews.com/feature/nbc-out/anti-gay-pastor-resigns-after-allegedly-being-prostitutes-n955926.

${ }^{5}$ BBC, America's 'Hate' Preacher; also see Paul Wittenberger, dir., Babylon USA (Phoenix, AZ: Framing The World Productions, 2017), 94 mins., accessed Aug 6, 2020, https://archive.org/details/BabylonUSA and Paul Wittenberger, dir., New World Order Bible Versions (Phoenix, AZ: Framing The World Productions, 2014), 99 mins., accessed July 30, 2019, https://archive.org/details/NewWorldOrderBibleVersionsFullMovie720.

${ }^{6}$ Apart from the film itself, see Steven L. Anderson, "Israel Moments 11-20," Faithful Word Baptist Church, August 2014, accessed May 13, 2019, http://www.faithfulwordbaptist.org/israel moments 11 20.html.

${ }^{7}$ Steven L. Anderson, “Did the Holocaust Really Happen?," Archive.org video, 37:09, 2015, accessed July 30, 2019, https:// archive.org/details/PastorStevenAndersonDidTheHolocaustReallyHappen.

${ }^{8}$ Deborah Lipstadt, "The Trump Administration's Flirtation With Holocaust Denial," The Atlantic, January 30, 2017, accessed March 1, 2020, https://www.theatlantic.com/politics/archive/2017/01/the-trump-administrations-softcore-

Matthew H. Brittingham. "'IThe Jews love numbers": Steven L. Anderson, Christian Conspiracists, and the Spiritual Dimensions of Holocaust Denial." Genocide Studies and Prevention 14, 2 (2020): 44-64. @2020 Genocide Studies and Prevention.

https://doi.org/10.5038/1911-9933.14.2.1721 
hoax" or "Holocaust myth," as he often refers to the Holocaust, is mostly a regurgitation of the pseudoscientific arguments made by a more established group of Holocaust deniers, Anderson adds a spiritual dimension to Holocaust denial to make it attractive to Christian viewers. ${ }^{9}$ In the following article, I argue this very claim-Anderson presents fellow Christians with arguments for Holocaust denial and sets Holocaust denial in a spiritual framework. He depicts Christianity and Judaism in cosmic battle, such that the "Holocaust myth" hinders the spread of Christianity. By examining the spiritual importance Anderson gives Holocaust denial, scholars gain insight into how individuals refashion genocide denial for their own needs and repackage it for particular audiences, an example of "how conspiracy narratives are mobilized within specific religious groups."10

I begin this article by discussing Christian conspiracists and theoretical issues in analyzing Holocaust denial on the web. I continue by briefly describing Marching to Zion, its production, narrative, and theological goals. ${ }^{11}$ While Anderson does not espouse Holocaust denial in this film, Marching to Zion shows Anderson's connection to Texe Marrs, ${ }^{12}$ a Christian conspiracist more actively involved in a wider network of what I call theocentric Christian conspiracists. I then consider Anderson's post-Marching to Zion Holocaust denial video, "Did the Holocaust Really Happen?" Through a close reading of this video, I show how Anderson gives Holocaust denial a spiritual meaning because, he believes, the Holocaust negatively impacts one of his ultimate goals, "soul-winning," or bringing lost souls to faith in Jesus. Though Anderson and fellow Christian conspiracists have a special theologically-driven interest in Jews and the Holocaust, their case shows how the discourse related to denying a particular genocide morphs when applied in specific contexts.

\section{Theocentric Christian Conspiracists and Holocaust Denial on the Web}

The following section makes several features of Anderson's Holocaust denial evident. First, Anderson is not alone in making theology central to his Holocaust denial. Anderson exists as part of a connected but still diffuse group of theologically-focused, antisemitic Christian conspiracists who deny the Holocaust. Second, Anderson and those of his ilk draw from (at least) two discursive traditions-Christian theology and antisemitic conspiracy theories. Naturally, these discursive traditions sometimes intersect and sometimes do not. In this particular section, it is important to show how they intersect in the case of Anderson and like-minded Christian conspiracists since it will remain a relevant theme throughout this study. Third, a window of opportunity has emerged for Anderson and similar antisemitic Christian conspiracists to adapt Holocaust denial discourse to their needs in ways that might not have been as readily apparent in the recent past, a product of changing Holocaust denial networks and new technologies.

holocaust-denial/514974/; also see Deborah Lipstadt, "Holocaust Denial: An Antisemitic Fantasy," Modern Judaism 40, no. 1 (2020), 75, accessed March 1, 2020, doi: https://doi.org/10.1093/mj/kjz019. For Lipstadt's influential early work, see Deborah Lipstadt, Denying the Holocaust: The Growing Assault on Truth and Memory (New York: Free Press, 1993). Some scholars refer to Holocaust denial as "negationism" and Holocaust deniers as "negationists." I have decided to use "Holocaust denial" and "Holocaust denier."

${ }^{9}$ Anderson jumped onto YouTube soon after the site appeared and developed a media strategy where associates posted a daily dose of his sermon clips online, see clip Steven L. Anderson, "Hardball Interview with Pastor Steven Anderson," YouTube video, 00:09:16-00:15:23, posted on June 29, 2017, accessed July 30, 2019, https://www.youtube.com/ watch?time continue $=280 \& v=S Y W U t 6 k$ Eog. As of August 2019, several of Anderson's videos I analyze in this article have been removed from YouTube or listed as private because of the site's changing policies. See Paris Martineau, "YouTube is Banning Extremist Videos. Will it Work?" Wired, June 5, 2019, accessed July 30, 2019, https://www.wired. com/story/how-effective-youtube-latest-ban-extremism/. Many of his videos and films can still be found at Archive. org. Where applicable, I reference timestamps for Anderson's videos according the versions uploaded to Archive.org.

${ }^{10}$ David G. Robertson, "Conspiracy Theories and the Study of Alternative and Emergent Religions," Nova Religio 19, no. 2 (2015), 8, accessed July 1, 2019, doi: https://doi.org/10.1525/nr.2015.19.2.5.

${ }^{11}$ Paul Wittenberger, dir., Marching to Zion (Phoenix, AZ: Framing The World Productions, 2015), 101 mins., accessed July 30, 2019, https://archive.org/details/PastorStevenAndersonMarchingToZion.

${ }^{12}$ Texe Marrs died while this article was being reviewed and edited for publication. I have decided to maintain the present tense when talking about his writing and thought. Dignity Memorial, "Obituary: Texe Marrs, July 15, 1944-November 23, 2019," Dignity Memorial, accessed August 5, 2020, https://www.dignitymemorial.com/obituaries/austin-tx/texemarrs-8938309. 
Brittingham

Anderson is an example of what I call theocentric Christian conspiracists. ${ }^{13}$ By "theocentric," I am not referring to the term's use within Christian theological discourse, but as the word commonly appears in English dictionaries, typically a variation of "centering on or directed toward God as a focus of interest, source of authority, etc." ${ }^{14}$ As scholars have noted, many conspiracists address religious issues in some fashion, but theocentric Christian conspiracists, I submit, focus their conspiracy narratives first and foremost on religious texts, theology, or divine prophecy. Secularlyoriented conspiracists, on the other hand, generally do not make religious texts, theology, or divine prophecy central to their conspiracies. ${ }^{15}$ As a fitting example, the above-mentioned Marrs, a close associate of Anderson's and the conspiracist "star" of Marching to Zion, aptly summarized the centrality of Christian scripture in directing his personal knowledge of conspiracies - "[t]hough I sought the counsel of men wise to the ways of the world, experts in the field of conspiracy science, only the Bible, I found, is able to grant me access to the key that would unlock that heavy door to find the ineffable mystery of iniquity." 16

Scriptural references abound in the work of Marrs, Anderson, and other theocentric Christian conspiracists, and their theological rationale is always forefront. Though I will not delineate the extent of its boundaries here, the concept of theocentric Christian conspiracists is flexible enough to encompass groups and individuals as diverse as Christian Identity and Pat Robertson, which means that theocentric Christian conspiracists can include antisemites and Holocaust deniers and those who are not. ${ }^{17}$

More specifically, I suggest theocentric Christian conspiracists like Anderson advance theologically-focused "superconspiracies." ${ }^{18}$ As Michael Barkun defines superconspiracies, they are "conspiratorial constructs in which multiple conspiracies are believed to be linked together hierarchically... At the summit of the conspiratorial hierarchy is a distant but all-powerful evil force manipulating lesser conspiratorial actors." ${ }^{19}$ Once again, superconspiracy is not only evident in the films, preaching, and blogposts of Steven Anderson, but is shared by a group of likeminded, antisemitic theocentric Christian conspiracist writers, such as Marrs, ${ }^{20}$ Edward Hendrie, ${ }^{21}$

\footnotetext{
${ }^{13}$ Michael Barkun defines conspiracy as "the belief that an organization made up of individuals or groups was or is acting covertly to achieve some malevolent end," see Michael Barkun, A Culture of Conspiracy: Apocalyptic Visions in Contemporary America, 2nd ed. (Berkeley: University of California Press, 2013), 3. There are legitimate concerns with Barkun's notion of "conspiracy belief," but I still find "superconspiracies" particularly helpful. On drawbacks to "conspiracy belief," see Lance deHaven-Smith, Conspiracy Theory in America (Austin: University of Texas Press, 2013), 37.

${ }^{14}$ Collins English Dictionary, s.v., "theocentric," accessed March 1, 2020, https://www.collinsdictionary.com/us/dictionary/ english/theocentric.

${ }^{15}$ Barkun, A Culture of Conspiracy, 68.

${ }^{16}$ Texe Marrs, Conspiracy of the Six-Pointed Star: Eye-Opening Revelations and Forbidden Knowledge About Israel, the Jews, Zionism, and the Rothschilds (Austin: RiverCrest Publishing, 2011), loc. 7772, Kindle.

${ }^{17}$ Without referring to it as such, Barkun offers an example what I call theocentric Christian conspiracism when addressing the writing of Texe Marrs and Pat Robertson on the Illuminati. On Marrs, Robertson, and the Illuminati, Barkun states, "[i]n the majority of [recent Illuminati literature], the alleged Illuminatist attack on revealed religion is a secondary motif, but in the works of Texe Marrs and Pat Robertson, it emerges as a central theme." See Barkun, $A$ Culture of Conspiracy, 52. Barkun on Marrs again, see Michael Barkun, Religion and the Racist Right: The Origins of the Christian Identity Movement, revised edition (Chapel Hill: University of North Carolina Press, 1997), 288-289.

${ }^{18}$ Barkun, A Culture of Conspiracy, 6.

${ }^{19}$ Ibid.

${ }^{20}$ Several relevant works by Texe Marrs include: Texe Marrs, Blood Covenant with Destiny: The Babylonian Talmud, the Jewish Kabbalah, and the Power of Prophecy (Austin: RiverCrest Publishing, 2018), Kindle; Texe Marrs, DNA Science and the Jewish Bloodline (Austin: RiverCrest Publishing, 2013), Kindle; Marrs, Conspiracy of the Six-Pointed Star; Texe Marrs, Feast of the Beast (Austin: RiverCrest Publishing, 2017), Kindle; Texe Marrs, Holy Serpent of the Jews: The Rabbis' Secret Plan for Satan to Crush Their Enemies and Vault the Jews to Global Dominion (Austin: RiverCrest Publishing, 2016).

${ }^{21}$ Edward Hendrie, Solving the Mystery of Babylon the Great: Tracking the Beast from the Synagogue to the Vatican, 2nd ed. (Great Mountain Publishing, 2012), Kindle; Edward Hendrie, Bloody Zion: Refuting the Jewish Fables That Sustain Israel's War Against God and Man (Great Mountain Publishing, 2012), Kindle.
} 
Michael Hoffman, ${ }^{22}$ and Peter Christian. ${ }^{23}$ While they do not hold exactly the same conspiratorial or theological views, they exhibit notable family resemblances, their theologically-focused antisemitism and Holocaust denial being most important for this study. For Anderson and similar antisemitic theocentric Christian conspiracists, they generally recognize Satan as the hidden force driving sinister world events. Satan uses very willing co-conspirators, "the synagogue of Satan" (i.e. Jews, referencing Rev. 2:9 and 3:9, King James Version [KJV]), ${ }^{24}$ who in turn create or manipulate a number of secret societies, governments, organizations, ideologies, and individuals to do their bidding. Marrs again offers a helpful example, this time of a superconspiracy in action:

The Synagogue of Satan! That's the evil group that God names. Not the Moslems [sic], not the Mormons, not even the Communists, the Masonic Lodge, or the Bilderbergers. Although each of these groups and others are, at some level, involved and culpable, God says it is the Synagogue of Satan that drives the conspiracy locomotive. The Synagogue of Satan is identified by Almighty God as the blasphemous and murderous entity which is the chief engineer of planetary chaos in the last days. ${ }^{25}$

It is important to note that Anderson is not at the center of any assortment of like-minded, antisemitic theocentric Christian conspiracists, if it even has a center. Marrs is much more attuned to the work of other theocentric Christian conspiracists than Anderson. However, Marrs and Anderson show their personal connections and family resemblances in Marching to Zion and media about Marching to Zion, as shown below.

Anderson's Holocaust denial is interesting, albeit disturbing, for the fact that he places theological convictions at the fore. While Christianity in particular has played and continues to play a role in the antisemitic rhetoric of many individuals and movements who deny the Holocaust, direct reliance on Christian scriptures and Christian theology has been rare in Holocaust denial discourse. A helpful example of this case can be observed in Committee for Open Debate on the Holocaust (CODOH), an internet forum for Holocaust deniers, which recently hosted a thread about Anderson's Holocaust denial. ${ }^{26}$ An experienced participant on the site, Rmbrmb21, brought up Anderson's Holocaust denial, but also opened the discussion with a notable caveat, "I don't know how much theology we want to get into on this forum, or how many of us are religious in any sense." ${ }^{27}$ Rmbrmb21's caveat demonstrates how, on one of the premier forums for Holocaust deniers, participants hardly ever address any connections between theology and Holocaust denial. In fact, Rmbrmb21 is entirely unaware of how many fellow forum participants are even religious "in any sense." Another experienced forum member, borjastick, responded to the thread in a similar fashion, "I hope the Mods allow your post to remain as it does show a wider understanding of the influence jews and I think israeli jews [sic], who I see as somewhat different, have over the Christian masses in the US." ${ }^{28}$ Once again, the fact that an experienced forum participant was uncertain whether theological discussions would be welcome on $\mathrm{CODOH}$ shows just how few of these discussions take place on the forum. Interestingly, a number of CODOH members appear to have religious convictions, as the thread attracted commenters who affirmed Anderson's theological views.

In light of the $\mathrm{CODOH}$ discussion referenced above, it is important to understand Anderson's place in the history and structure of Holocaust denial online. Aside from scholarship on the legality of legislating Holocaust denial online, few scholars have dealt seriously with Holocaust denial in cyberspace. ${ }^{29}$ In 2017, however, William Allington published a noteworthy journal article on

\footnotetext{
${ }^{22}$ Michael Hoffman, Judaism's Strange Gods, 2nd ed. (Independent History \& Research Co., 2000); Michael Hoffman, Judaism Discovered: A Study of the Anti-Biblical Religion of Racism, Self-Worship, Superstition and Deceit, 3rd ed. (Independent History \& Research Co., 2008).

${ }^{23}$ Peter Christian, Lucifer's Army: An Exposé of Talmudic Tyranny (Barnes Review, 2017); Peter Christian, One Nation Under Zion: Zionist Influence on America (Barnes Review, 2013); Peter Christian, The Work of All Ages: The Ongoing Plot to Rule the World from Biblical Times to the Present (Barnes Review, 2010).

${ }^{24}$ Marrs, Blood Covenant with Destiny, loc. 482, Kindle; Marrs, Conspiracy of the Six-Pointed Star, loc. 751, Kindle.

${ }^{29}$ William Allington, "Holocaust Denial Online: The Rise of Pseudo-Academic Antisemitism on the Early Internet," Journal of Contemporary Antisemitism 1, no. 1 (2017), 35, accessed July 15, 2019, doi: https://doi.org/10.26613/jca/1.1.4; also
} 
Brittingham

Holocaust denial online, particularly its structural growth in the early days of the World Wide Web. ${ }^{30}$ In this article, Allington focuses on "the general hierarchy of the movement; the differences between the creators and consumers of material." ${ }^{\prime 11}$ His hierarchy divides specifically between what he calls organized Holocaust denial and casual Holocaust denial. Defining organized Holocaust denial, Allington states, "[o]rganized Holocaust denial resembles a school of political or historical thought, with named and identifiable figures at the center and the creation of an infrastructure behind the movement." 32 Put more simply, organized Holocaust deniers are "the writers and original distributors of [Holocaust denial] material." ${ }^{33}$ Early organized Holocaust deniers on the web, like their pre-internet counterparts, were obsessed with appearing rational or reasonable. Hence, organized Holocaust deniers have been those who "establish institutions, publish journals, hold conferences, and defend their theories in the public sphere and, if necessary, law courts." ${ }^{34}$ Casual Holocaust deniers, on the other hand, tend to be the "anonymous promoters of Holocaust denial" in cyberspace. They "take the material from organized Holocaust deniers and spread it on message boards and via emails and social media so the movement can grow." ${ }^{\prime 35}$ Casual Holocaust deniers may diffuse Holocaust denial online for a variety of ideological reasons, and Allington does not concern himself with guessing at ideological rationales.

While Allington uses the organized versus casual framework in describing the early stages of Holocaust denial online, another scholar, Nicholas Terry, has focused on Holocaust denial in "web 2.0." Though it might seem that web 2.0, identified by expansions in social media and usergenerated content, could be a godsend for Holocaust deniers, in fact "'Revisionists' have found it difficult to compete for attention in a crowded marketplace for fringe ideas, and have been eclipsed by a number of new internet-based conspiracy theories." 36 Terry states further,

despite the return of conspiracist anti-Semitism after 9/11 and a rise in anti-Zionism since the start of the Second Intifada in September 2000, Holocaust denial has been unable to profit from these trends and has failed to attract intellectuals or activists in significant numbers in Western societies. Thus, while Holocaust denial continues to have great brand recognition, it now has surprisingly few customers. ${ }^{37}$

Even one-time stalwarts of Holocaust denial have backtracked on former positions or have ceased contributing to this increasingly unpopular cause. Hardcore Holocaust denial has also become less popular in many far-right circles. Promoting it could prove publicly damaging and would probably interfere with practical political goals. ${ }^{38}$ Instead, "Holocaust denial has been cut loose to fend for itself as just one of many fringe conspiracy theories peddled on the internet." 39

It is worth considering Anderson's place in Allington's relationship between organized and casual Holocaust denial, as well as Anderson's place in Terry's description of Holocaust denial in web 2.0. In terms of Allington's schema, Anderson resembles casual Holocaust denial in many respects. Anderson isn't invested in sculpting the infrastructural aspects of Holocaust denial and doesn't talk about Holocaust denial at every opportunity. He is a pastor with a variety of concerns about the state of the contemporary world, and he promotes a number of conspiracy

\footnotetext{
see Terry, Holocaust Denial in the Age of Web 2.0; Michael Shermer and Alex Grobman, Denying History: Who Says the Holocaust Never Happened and Why Do They Say It? (Berkeley: University of California Press, 2009).

${ }^{30}$ Allington, Holocaust Denial Online, 36-37.

${ }^{35}$ Ibid. For more on pseudo-academic Holocaust denial, see Lipstadt, Denying the Holocaust, 120, 142.

${ }^{36}$ Terry, Holocaust Denial in the Age of Web 2.0, 34.

${ }^{38}$ Ibid., 37-53, especially see $44-46$.
}

${ }^{31}$ Ibid., 37.

32 Ibid.

${ }^{33}$ Ibid.

${ }^{34}$ Ibid.

${ }^{37}$ Ibid., 34-35.

${ }^{39}$ Ibid., 53. 
theories. ${ }^{40}$ Anderson has actually been far more invested in propagating broader antisemitic tropes, such as Jews are liars, Jews control the media, Jews own the banks, etc., than talking specifically about the Holocaust. Anderson's Holocaust denial is bound to his antisemitism and anti-Israel agenda, which emerge from his interpretation of the Bible.$^{41}$ Likewise, Anderson's pseudoscientific arguments are taken directly from the writings of prominent Holocaust deniers who put forward the image of being rational, reasonable, and academic. Anderson takes the pseudoscientific work of these organized Holocaust deniers and owns it, so to speak, blending it into his theologicallyfocused antisemitism and reframing it for his largely Christian viewership. As a public figure with an established audience and lines of communication, he is a casual Holocaust denier who, unlike the casual Holocaust deniers Allington describes, does not rely on the anonymity offered by the internet to spread Holocaust denial. Anderson blurs the lines between the roles historically played by organized and casual Holocaust deniers. He is not one of the "writers and original distributors" 42 of Holocaust denial material, but he assumes a more public role than anonymous casual Holocaust deniers.

The fact that, as Terry states, "Holocaust denial has been cut loose to fend for itself as just one of many fringe conspiracy theories peddled on the internet" ${ }^{43}$ offers an explanation for why Anderson can take such a public role in supporting Holocaust denial. With the declining authority of a prior generation of diehard, organized Holocaust deniers, due to infighting, organizational failure, and age, new proliferators of Holocaust denial have begun to fill the vacuum they left behind. Especially notable has been the prominence of conspiracists in filling this void. Terry finds that "The conspiracist scene has in fact become one of the few potential growth areas for negationism in recent years." 44 Further, a number of Holocaust deniers and Holocaust denial websites obsessed with appearing rational, reasonable, and scientific have been willing to risk that image by welcoming Holocaust deniers who present their denial as one of many other "crank" conspiracy theories, such as moonlanding conspiracies, 9/11 conspiracies, JFK assassination conspiracies, etc. ${ }^{45}$ This is not to say that appearing rational, reasonable, or scientific is not important. Like other conspiracists who peddle Holocaust denial, Anderson clearly feels the need to appear rational or reasonable by citing the work of "scientific" Holocaust deniers. Likewise, like pseudo-academic Holocaust deniers, many conspiracy theorists generally adopt a "quasi-academic style" for "a plausible appearance and an aura of respectability." ${ }^{46}$ Anderson is no different in these regards. Yet, as a theocentric Christian conspiracist, Anderson is invested in illuminating the supernatural, which, at least in the eyes of diehard pseudo-academic Holocaust deniers, does not appear rational, reasonable, or scientific. He mixes the supposedly rational, reasonable, or scientific discourse of previous generations of organized Holocaust deniers with the prophetic. I now briefly turn toward examining his theology and connections to other Christians who espouse antisemitic conspiracies and Holocaust denial, exemplified in the film Marching to Zion.

${ }^{40}$ Anderson is the visual head of what is called the New IFB, a group of IFB pastors who share particular theological views. He is often engaged in theological infighting with IFB pastors who oppose his teaching. See "What is the New IFB Movement?", The New Independent Fundamental Baptist Movement, accessed July 30, 2019, https://web.archive. $\mathrm{org} / \mathrm{web} / 20191211161128 / \mathrm{https} / /$ www.thenewifb.com/what-is-the-new-ifb. As of February 2020, infighting may have temporarily halted or permanently damaged the movement, and the New IFB's website has been shut down. The link I have included is a screen capture dated December 11, 2019. Also see Hatewatch Staff, "In the Midst of Infighting, Anti-LGBTQ Church Network's Website and Social Media Disappear," Hatewatch (blog), Southern Poverty Law Center, February 21, 2020, accessed April 15, 2020, https://www.splcenter.org/hatewatch/2020/02/21/midst-infightinganti-lgbtq-church-networks-website-and-social-media-disappear.

${ }^{41}$ See, for example, Anderson's blog: Steven L. Anderson, "Muslim Hate and Pro-war Propaganda," Steven L. Anderson (blog), October 9, 2014, accessed July 30, 2019, https://sanderson1611.blogspot.com/2014/10/muslim-hate-and-prowar-propaganda.html; also see Texe Marrs and Framing the World, "Texe Marrs Interviews Steven Anderson About 'Marching to Zion' Part 1,' interview by Texe Marrs, May 5, 2015, YouTube video, 1:03:12, accessed July 30, 2019, https://www.youtube.com/watch?v=8vbUkXm8K3g.

${ }^{42}$ Allington, Holocaust Denial Online, 37.

${ }^{43}$ Terry, Holocaust Denial in the Age of Web 2.0, 53.

${ }^{44}$ Ibid., 48.

${ }^{45}$ Ibid.

${ }^{46}$ Jovan Byford, Conspiracy Theories: A Critical Introduction (New York: Palgrave Macmillan, 2011), 89; also see Barkun, A Culture of Conspiracy, 187. 


\section{Framing the World, Marching to Zion, and Texe Marrs}

The following section considers the 2015 film Marching to Zion. It reveals Anderson's antisemitic theological views, his association with Texe Marrs, and how he frames Jews, Judaism, and Israel before ever talking about the Holocaust. As noted above, if "Holocaust denial has been cut loose to fend for itself as just one of many fringe conspiracy theories peddled on the internet," ${ }^{47}$ this means that Holocaust denial in its most recent iterations and contexts should be understood in relation to relevant conspiracy theories. Furthermore, while Anderson and Marrs might have some nuanced differences on particular theological issues, they showcase significant family resemblances in matters of theology and approach to Jews, Judaism, Israel, and, ultimately, the Holocaust. It is important to understand Anderson's theology, media, and networks since they are vital to the messages relayed his Holocaust denial video.

Since Anderson and Wittenberger teamed up, Framing the World has produced a number of "documentaries" (read: propaganda films). ${ }^{48}$ Marching to Zion was the first of their films to fully tackle their views on the intersection of Christianity, Jews, Judaism, and Israel. According to Anderson, Marching to Zion is a film that "exposes the fraud of the modern-day nation of Israel and the fraud of the religion known as Judaism." ${ }^{49}$ In terms of theological views, Anderson's Faithful Word Baptist Church is opposed to Christian Zionism, which scholar Stephen Spector broadly defines as "Christians whose faith, often in concert with other convictions, emotions, and experiences, leads them to support the modern state of Israel as the Jewish homeland." ${ }^{50}$ Anderson often slips into equating Christian Zionism with dispensationalist theology. Though the two are wedded in the popular imagination, and often in American geopolitics, they are not synonymous. ${ }^{51}$ Anderson also cares little about the nuanced developments of dispensationalism over time. ${ }^{52}$ That said, the various iterations of dispensationalist theology have, as academics indicate, generally emphasized "the uniqueness and importance of both Israel and the Church" ${ }^{53}$ in God's divine plan. By theorizing a special, ongoing Jewish relationship with God, "Dispensationalism enhanced the conviction that the Jewish people are the apple of God's eye, set aside for the Lord's blessing." ${ }^{54}$ Opposed to dispensationalist theology, Anderson promotes supersessionism, also known as replacement theology, the belief that the New Covenant of Jesus Christ has superseded the Old Covenant made with Israel. Many who hold to replacement theology generally believe that modern Jews do not constitute God's chosen people. ${ }^{55}$ Rather, the Christian church took on the mantle of God's chosen people with the New Covenant's inclusion of gentiles into the people of God. Marching to Zion is constructed around a series of arguments against dispensationalist Christian

${ }^{47}$ Terry, Holocaust Denial in the Age of Web 2.0, 53.

48 "Framing the World Store," Framing the World, accessed July 30, 2019, https://framingtheworld.com/store/ols/ categories/dvds. The New IFB is heavily invested in using "documentaries" to reach fellow Christians and the unsaved. See YouTube, "New IFB Documentaries," YouTube Channel, accessed May 18, 2020, https://www.youtube. com/channel/UCN5OBnOh1-QGZ1sQqOxflbg/videos.

${ }^{49}$ Anderson, Did the Holocaust Really Happen?, 00:00:00-00:00:24.

${ }^{50}$ Stephen Spector, Evangelicals and Israel: The Story of American Christian Zionism (Oxford: Oxford University Press, 2009), 3; also see Yaakov Ariel, "An Unexpected Alliance: Christian Zionism and its Historical Significance," Modern Judaism 26, issue 1 (2006), 74-100, accessed July 10, 2019, doi: https://doi.org/10.1093/mj/kjj005.

${ }^{51}$ On the problem with rigidly coupling Christian Zionism and dispensationalism, see Matt Westbrook, "Broadcasting Jesus' Return: Televangelism and the Appropriation of Israel through Israeli-Granted Broadcasting Rights," in Comprehending Christian Zionism: Perspectives in Comparison, eds. Göran Gunner and Robert O. Smith. (Minneapolis: Fortress Press, 2014), 79-82; also see Samuel Goldman, God's Country: Christian Zionism in America (Philadelphia: University of Pennsylvania Press, 2018), 4-11.

${ }^{52}$ Mark S. Sweetnam, "Defining Dispensationalism: A Cultural Studies Perspective," Journal of Religious History 34, no. 2 (2010), 192-194, accessed July 20, 2019, doi: https://doi.org/10.1111/j.1467-9809.2010.00862.x.

${ }^{53}$ Ibid., 202.

${ }^{54}$ Spector, Evangelicals and Israel, 112.

${ }^{55}$ Hillary Kaell, Walking Where Jesus Walked: American Christians and Holy Land Pilgrimage (New York: New York University, 2014), 37-38; Yaakov Ariel, An Unusual Relationship: Evangelical Christians and Jews (New York: New York University, 2013), 8, 19-20; also see Yaakov Ariel, "Israel in Contemporary Evangelical Christian Millennial Thought," Numen 59, no. 5-6 (2012), 471, 481, accessed July 1, 2019, doi: https://doi.org/10.1163/15685276-12341235. 
Zionists, attempting to prove that their support for the State of Israel is theologically misguided. ${ }^{56}$

To prove Christian Zionists wrong, Anderson and Wittenberger interviewed seven Baptist pastors, the owners and operators of a DNA testing company, Texe Marrs, and four Jewish community leaders and rabbis in Arizona (Conservative, Reform, Orthodox, and Humanist). ${ }^{57}$ Why interview Jewish community leaders if the film focuses on theological debates within Christianity? By interviewing rabbis, Framing the World hopes to demystify, for Christians, what modern Jews believe. Anderson wants to show viewers that Jews are far from being "the apple of God's eye" because Judaism hardly shares any theological beliefs with fundamentalist or conservative Christians. Framing the World assumes that dispensationalist Christian Zionists have an ossified view of Jews and Judaism. Throughout the film, Anderson and Wittenberger essentially highlight the historic dynamism of Judaism from the Talmud to modern times. The intent, however, is not to show the religious vibrancy of Judaism over millennia, but to show how Judaism became mixed with satanic ideas and practices, as well as how Jews conspired against Christians and the church. Marching to Zion, therefore, exhibits a dual program: (1) deconstructing what many fundamentalist or conservative Christians might believe about Judaism, and (2) reconstructing what Jews and Judaism are from an antisemitic theocentric Christian conspiracist point of view. Because the Jews rejected Jesus, Judaism is the aforementioned "synagogue of Satan." The synagogue of Satan is a conspiring cabal of Jews attempting to manipulate world affairs, particularly at the end of days. In terms of the interviews with Jewish community leaders, Anderson used these four Jewish figures to speak for all Jews everywhere. According to these interviewees, Framing the World duped them into participating in Marching to Zion. ${ }^{58}$ Anderson disputes this account and claims that he provided all the interview questions in advance. Nevertheless, he admits to not being forthright about the intentions of the film. ${ }^{59}$

Anderson and Wittenberger spend considerable time in Marching to Zion talking to Marrs. Marrs, who personally calls his work "conspiracy science," has long sought to expose the "mysterious 'they"' directing nefarious world affairs..$^{60}$ Using the Bible, but undoubtedly influenced by other conspiracists, he personally came to the conclusion that the "synagogue of Satan" (i.e. Jews) was behind the forces of evil in this world. ${ }^{61}$ In his thought, Jews are part of a cosmic dichotomy. ${ }^{62}$ In this dichotomy, Christianity professes a spiritual kingdom while Judaism maintains a carnal kingdom, sentiments drawn from a long history of anti-Jewish and antisemitic thought in Christianity ${ }^{63}$ Sharing this view with Anderson, they call contemporary Jews "Israel after the flesh." ${ }^{64}$ With

${ }^{56}$ It is important to note that replacement theology does not necessarily lead to delegitimizing the State of Israel and is not necessarily opposed to Christian Zionism. Again, see Westbrook, Broadcasting Jesus' Return, 79-82; and Goldman, God's Country, 4-11.

${ }^{57}$ Steven L. Anderson, “New Documentary-Marching to Zion," Steven L. Anderson (blog), July 27, 2014, accessed July 30 , 2019, https://sanderson1611.blogspot.com/2014/07/new-documentary-marching-to-zion.html.

${ }^{58}$ Haaretz, “US Pastor Dupes Rabbis into Anti-Semitic Film," Haaretz, January 1, 2015, accessed July 30, 2019, https://www. haaretz.com/jewish/u-s-pastor-dupes-rabbis-into-anti-semitic-film-1.5346628. Anderson references his interviews throughout a sermon series as well, see Truth in Genesis, "The Jews and Their Lies Part 1 of 2," YouTube video, 1:04:11, uploaded July 5, 2015, accessed July 30, 2019, https://www.youtube.com/watch?v=ml-x4VaEaK0; also see Truth in Genesis, "The Jews and Their Lies Part 2 of 2," YouTube video, 1:05:43, posted July 12, 2015, accessed July 30, 2019, https://www.youtube.com/watch?v=MYrQXn9IUlM\&t=3073s.

${ }^{59}$ Steven L. Anderson, “Live Phone Q\&A with Pastor Steven L Anderson (11/25/14 6:00pm),” YouTube video, 3:00:10, uploaded November 25, 2014, accessed July 30, 2019, https://www.youtube.com/watch? v=aFhxXngZ2i8, 02:00:5002:03:11; also see David Neiwert, "Arizona Pastor Boasts about Tricking Rabbis into Participating in Anti-Semitic Film," Hatewatch (blog), Southern Poverty Law Center, December 12, 2014, accessed May 18, 2020, https://www. splcenter.org/hatewatch/2014/12/12/arizona-pastor-boasts-about-tricking-rabbis-participating-anti-semitic-film.

${ }^{60}$ Marrs, Conspiracy of the Six-Pointed Star, loc. 7705, 7742, Kindle.

${ }^{61}$ Ibid., loc. 7775, Kindle; also see loc. 751.

${ }^{62}$ Ibid., loc. 8664, Kindle.

${ }^{63}$ On Christianity and the understanding of Jews as materialistic rather than spiritual, see Stephen H. Norwood, "Convergent Anti-Zionisms: The American Far Left and Far Right," in Anti-Judaism, Antisemitism, and Delegitimizing Israel, ed. Robert S. Wistrich (Lincoln: University of Nebraska Press, 2016), 119.

${ }^{64}$ Anderson used the words "Israel after the flesh," see Marrs, Texe Marrs Interviews Steven Anderson About 'Marching to Zion' Part 1, 00:44:07-00:44:27; Marrs asserts the same, see Conspiracy of the Six-Pointed Star, loc. 347, Kindle. 
Christianity and Judaism locked in cosmic battle, the State of Israel is the latest realization of a Jewish carnal kingdom on earth. Because Christianity seeks a spiritual kingdom, Judaism's desire for a carnal kingdom means that it must be aligned with Jesus' opposite, Satan. Marrs sees all nonChristian religions as satanic, but Judaism appears particularly pernicious in his writings. Anderson is similar on this account. On the one hand, he claims Islam is "just as satanic as Judaism"65; on the other hand, he considers Jews to have a special relationship with Satan. In an interview with Marrs, Anderson affirmed this notion:

Israel after the flesh is an abomination today. You know, they're wicked. They are the most blasphemous people toward our Lord Jesus Christ. When it comes to the religions of the world, the religion that is the most blasphemous is Judaism. And that's why God identified Judaism as the synagogue of Satan. ${ }^{66}$

In Marrs and Anderson's understanding of Jewish history, Judaism's embrace of satanic elements can be recognized in anti-Christian sentiments in the Talmud ${ }^{67}$ Through various means, such as Kabbalah and Zionism, Judaism spread its pernicious, pagan-inspired practices and materialism into other religious groups, ideologies, social movements, political institutions, and secret societies, like post-Vatican II Catholicism, the New Age movement, the Masonic Lodge, and even dispensationalism. ${ }^{6}$ Secular Jews are not necessarily exempt either. Rather, there is a sense in which secular Jews still do Satan's work. Marrs and Anderson suggest that secular Jews inherit the sinful heritage of Judaism through their connection to supposedly evil ideologies and movements inspired by Judaism, such as socialism and Zionism. They believe Jews control the publishing industry, Hollywood, the news media, and much of global finance. ${ }^{69}$ These two theocentric Christian conspiracists make sure to claim that not all Jews knowingly participate in the global Jewish conspiracy; many Jews might be duped by Jewish leaders, e.g. rabbis, the Israeli government, Jewish socialists, Jewish philanthropists, etc. ${ }^{70}$ Despite attempting to hedge their bets, Anderson and Marrs often utilize all-encompassing antisemitic rhetoric to demonize all Jews who have not accepted Jesus as messiah, the one way Jews can disentangle themselves from Judaism's satanic tentacles.

By now, it should go without saying that Anderson is clearly an antisemite. He fits the International Holocaust Remembrance Alliance's (IHRA) "working definition of antisemitism" in "making stereotypical allegations about Jews as such or the power of Jews as collective."71 He especially fits the working definition in two ways I explore in the next section, namely by "denying the fact, scope, mechanisms (e.g. gas chambers) or intentionality of the genocide of the Jewish people at the hands of National Socialist Germany and its supporters and accomplices during World War II (the Holocaust)," and by "accusing the Jews as a people, or Israel as a state, of inventing or exaggerating the Holocaust." 72

\section{“What's the real Holocaust?": Steven Anderson's Holocaust Denial}

This final section presents the meat of my discussion on Anderson and how he frames the spiritual

\footnotetext{
${ }^{65}$ Anderson, Did the Holocaust Really Happen?, 00:34:20.

${ }^{66}$ Marrs, Texe Marrs Interviews Steven Anderson About 'Marching to Zion' Part 1, 00:44:07-00:44:27.

${ }^{67}$ Marrs, Conspiracy of the Six-Pointed Star, loc. 457, 534, 706, 871, 1160, 1236, 1332, Kindle.

${ }^{68}$ Ibid., loc. 460, 532, 906, 4938, Kindle; especially loc. 7787, 8524. Similarly, Barkun, A Culture of Conspiracy, 67.

${ }^{69}$ Texe Marrs and Framing the World, “Texe Marrs Interviews Steven Anderson About 'Marching to Zion' Part 2," YouTube video, 1:02:46, uploaded May 6, 2016, accessed July 30, 2019, https://www.youtube.com/ watch? $\mathrm{v}=3 \mathrm{HaBBRsHTOY}, 00: 05: 32$ and 00:06:28-00:06:38.

${ }^{70}$ This is a theme in, for example, Marrs, Conspiracy of the Six-Pointed Star, loc. 3145, Kindle; also see Anderson, Did the Holocaust Really Happen?

${ }^{71}$ American Jewish Committee, The Working Definition of Anti-Semitism: What Does It Mean, Why Is It Important, and What Should We Do With It? (New York: American Jewish Committee, n.d.), see page 6, accessed February 10, 2020, https:// www.ohchr.org/Documents/Issues/Religion/Submissions/[BI-Annex1.pdf.

${ }^{72}$ Ibid., 7.
} 
implications of the Holocaust. While I have been building to this point, the broader scope of his theological views, antisemitism, and similarities to other theocentric Christian conspiracists remains relevant. One could surmise that, in a sense, Anderson needs to deny the Holocaust. I do not suggest that it is a theological imperative. Instead, the Holocaust could represent the epitome of potential resistance to his religious aims. The Holocaust can be seen as a challenge to Christianity (because of the Christian history of anti-Judaism and antisemitism), as a force for cementing Jewish identity, and as generating sympathy for Jews, Judaism, and Israel. Denying the Holocaust wipes away these potential obstacles and others like them.

While Anderson has some different views than Marrs, they both draw on similar arguments for their Holocaust denial. In "Did the Holocaust Really Happen?," Anderson exhibits some of core traits of Holocaust denial outlined by Allington (referencing the work of Michael Shermer and Alex Grobman): Anderson denies "any 'Final Solution' to exterminate the Jewish people," denies "the existence of any extermination facilities," especially the gas chambers, and denies "the accepted death toll of five to six million Jews." He is ignorant, willfully or not, of the nuances of the Holocaust as "not a single event but rather a collective term describing a long series of events spread over many nations."73

Apart from what he denies, the strategies Anderson uses for popularizing Holocaust denial among Christians need to be considered more thoroughly. Anderson begins his video by appealing to Christian viewers with biblical references. He first tells the viewer not to "get upset, and angry, and emotional"74 before hearing his case for Holocaust denial. Anderson quotes the Book of Proverbs as justification, "He that answereth a matter before he heareth it, it is folly and shame unto him." ${ }^{\prime 75}$ In other words, or so the prooftext goes, the viewer needs to listen to Anderson before closing the video simply because he's questioning whether the Holocaust happened. Anderson uses these prooftexts, and others like it, to try and keep the Christian viewer tuned in, even potentially guilting them into hearing his case. While such biblical prooftexting is certainly uncommon among most historic and contemporary Holocaust deniers, in light of his likely audience, the consistent use of biblical references helps Anderson construct his image as a religious authority figure with spiritual insights into the Holocaust.

Anderson mixes his biblical appeal with strategies other Holocaust deniers regularly employ to deflect immediate criticism. Throughout the video, he insists that viewers do the research for themselves, rather than follow intuition, popular opinion, or the research of reputable scholars. Presumably, the viewer will discover holes in what he calls the "official version" (described below) of the Holocaust by digging deeper into the so-called facts; at least as he defines what digging deeper entails. ${ }^{76}$ In another example of deflection, Anderson appears to plead ignorance, making claims like "it is impossible for me... you know, in 2015 America, to tell you exactly what happened over there on the other side of the world seventy years ago." ${ }^{\prime 77}$ Still, he consistently doubles down on his denial because "the story doesn't add up." ${ }^{\prime 78}$ Whether consciously tapping into strategies employed by other Holocaust deniers or other conspiracists more broadly, these strategies allow Anderson to appear simply like an interested individual (though simultaneously a religious authority figure) who notices discrepancies and wants to explore them. In this way, Anderson self-fashions the image of a reasonable layman, signifying he will dispassionately dissect the facts for viewers. The "reasonable layman" image works in concert with the "religious authority figure" image, the latter of which recognizes the deeper impact of the Holocaust, its spiritual significance.

Anderson utilizes another strategy for diffusing criticism, one he shares with Marrs and similar antisemitic Christian conspiracists. As briefly alluded to above, Anderson seeks to distance himself from racists and neo-Nazis. Basically, from the start of "Did the Holocaust Really Happen?,"

\footnotetext{
${ }^{73}$ Shermer and Grobman in Allington, Holocaust Denial Online, 35.

${ }^{74}$ Anderson, Did the Holocaust Really Happen?, 00:01:45-00:02:40.

${ }^{75}$ Ibid., 00:01:45-00:02:40; citing Proverbs 18:13, King James Version (KJV).

${ }^{76}$ Ibid., 00:00:38-00:00:55.

${ }^{77}$ Ibid., 00:15:45-00:16:07.

${ }^{78}$ Ibid., 00:16:02-00:16:12.
} 
Anderson ensures viewers, "I don't have a racist bone in my body" and "I am not pro-Hitler or pro-Nazi or pro-National Socialist." ${ }^{79}$ On other occasions, Anderson has shown an awareness of the fact that the Anti-Defamation League and Southern Poverty Law Center have labeled him a racist and an antisemite. Throughout his ministry, Anderson has been consistent in claiming he isn't a racist or an antisemite.$^{80}$ In fact, Anderson and theocentric Christian conspiracists in his circle are outspoken in denouncing racism and racist movements as wholly unbiblical. In an interview between Marrs and Anderson, for example, Anderson stated, "I am not going to glory in being a white person, the Bible says 'God forbid that I should glory save for the cross of our Lord Jesus Christ'... The only thing that matters is: are you in Christ? If you're not in Christ, I don't care what your pedigree is you're not one of the chosen." ${ }^{81}$ Marrs and Anderson, as well as other Christians with similar views, often pat each other on the back for supposedly being against racism and antisemitism, which, in their eyes, are labels opponents use to silence biblical truth. As Christians who believe Jesus offers the only path to salvation, Marrs, Anderson, and their coterie are not afraid to state they are anti-Judaism, but they ardently reject being called racist or antisemitic, the latter of which they clearly understand to be exclusively race-based Jew hatred. As an example of their self-congratulatory language, in the same interview just mentioned Marrs commended Anderson for his anti-racism, saying "It seems to me... that you oppose racism. You're sort of a civil rights leader, in a favorable way, biblically... You're opposed to somebody that says this group or that group is, uh, God's chosen because of the color of their skin or their race or whatever." 82 It is important to note, however, that in the context of the interview the hidden sentiment is that Jews who believe they are God's chosen people are the true racists, also a common view held by likeminded, antisemitic theocentric Christian conspiracists. ${ }^{83}$

To explore the issue of race further, in Marching to Zion Anderson uses genetic testing to scientifically prove a spiritual claim attributed to the Apostle Paul in the Epistle to the Galatians, that "there is neither Jew nor Greek" in God's kingdom. ${ }^{84}$ According to Anderson, genetic testing shows how every human has ties to a variety of ethnic groups. So, as the logic goes, genetic testing definitively proves there are no racial, ethnic, or genealogical barriers to all people becoming united in Jesus Christ. In other words, God gave Paul's claim about spiritual unity a physical manifestation - the genetic code of every human. In one scene in Marching to Zion, Anderson and Wittenberger visit a laboratory to have their own DNA tested. Anderson celebrates his results, which apparently indicate African, Asian, and Jewish ancestry. As he interprets his results, modern genetic testing proves that Anderson himself is a kind of microcosm of scripture's teachings. ${ }^{85}$ The fact that Anderson revels in being ethnically or racially mixed distinguishes his approach from that of Holocaust deniers with explicit neo-Nazi or white supremacist leanings.

Further in "Did the Holocaust Really Happen?," Anderson states that he does not doubt Hitler

\footnotetext{
${ }^{79}$ Ibid., 00:00:56-00:01:23.

${ }^{80}$ For example, Marrs and Framing the World, Texe Marrs Interviews Steven Anderson About 'Marching to Zion' Part 1, 00:23:35-00:23:40; there, he says, "This has nothing to do with race, and they will try to play that race card, but I believe that God has made all nations of the earth of one blood."

${ }^{81}$ Ibid., 00:26:50-00:27:19.

${ }^{82}$ Ibid., 00:22:28-00:22:58; also see Wittenberger, Marching to Zion, beginning at 00:58:18.

${ }^{83}$ The notion that Jews are the real racists appears often in Marrs' writing. Marrs, DNA Science and the Jewish Bloodline, loc. 471, Kindle; Marrs, Conspiracy of the Six-Pointed Star, loc. 6104, Kindle; Marrs, Blood Covenant With Destiny, loc. 1967, Kindle; also see Hoffman, Judaism Discovered.

${ }^{84}$ Citing Galatians 3:28, KJV; Faithful Word Baptist Church, “'Marching to Zion' Full Movie Transcript," Faithful Word Baptist Church, May 14, 2015, accessed August 1, 2019, https://www.faithfulwordbaptist.org/m2z full english.html.

${ }^{85}$ Wittenberger, Marching to Zion, 01:13:16-01:30:48; also see Steven L. Anderson, “I'm North African!" Steven L. Anderson (blog), August 14, 2014, accessed July 30, 2019, https://sanderson1611.blogspot.com/2014/08/im-north-african. html; Steven L. Anderson, "I Have Jewish DNA!" Steven L. Anderson (blog), September 2, 2014, accessed July 30, 2019, https://sanderson1611.blogspot.com/2014/09/i-have-jewish-dna.html; Steven L. Anderson, "I'm Blacker than I Thought!" Steven L. Anderson (blog), September 3, 2014, accessed July 30, 2019, https://sanderson1611.blogspot. com/2014/09/im-blacker-than-i-thought.html; Steven L. Anderson, “My Mom is Part Asian!” Steven L. Anderson (blog), September 4, 2014, accessed July 30, 2019, https://sanderson1611.blogspot.com/2014/09/my-mom-is-part-asian.html; Steven L. Anderson, "My 92 Year-Old Grandma's DNA Results," Steven L. Anderson (blog), September 15, 2014, accessed July 30, 2019, https://sanderson1611.blogspot.com/2014/09/my-92-year-old-grandmas-dna-results.html.
} 
hated Jews and was a racist; he also does not doubt that Jews died in WWII. ${ }^{86}$ Rather, he disputes that six million Jews died at the hand of the Nazis. In terms of evidence, he largely regurgitates the pseudoscientific arguments of organized Holocaust denial, the arguments marshaled to make Holocaust denial appear reasonable or rational. However, he occasionally imbues these more historically common pseudoscientific arguments with spiritual meaning. The most notable example emerges from his discussion of Auschwitz. Claiming that Auschwitz was a labor camp and not a death camp, his primary evidence rests on the memorial plaques various governments placed and replaced at Auschwitz after the war. A fairly common focal point for Holocaust deniers, when the plaques at Auschwitz were replaced or updated, the stated number of those murdered changed, from 4 million to 1.5 million to 1.1 million. Yet, Anderson finds, the overall figure of six million always stays the same in public discourse. How is that possible? Anderson's understanding of the history and politics of these memorial plaques is superficial, and reputable scholars have already addressed seeming discrepancies. ${ }^{87}$ For Anderson, however, the six million total always remains unchanged because the number was "foreordained." By "foreordained," Anderson hints at two levels of numerical significance, one historical and one spiritual. First, Anderson's use of "foreordained" relies on a dubious interpretation of newspaper reports from before WWII, which reportedly hinted at six million Jews eventually dying in massive European conflict. In other words, Jews had already arrived at the six million figure long before Hitler ever came to power. Again, this so-called historical evidence harkens to the work of a generation of Holocaust deniers obsessed with using "rational" or "reasonable" arguments in their denial.

The second sense of "foreordained" adds a spiritual dimension to the six million number. Citing the Kabbalah and gematria as examples, Anderson claims that "the Jews love numbers" and the number six is of particular importance - "that number is like a magic number to them... it's not really based on real history or science." 88 Anderson then cites the Six-Day War, the six-pointed Star of David (a satanic symbol according to Anderson), and the six main death camps of the "Holocaust myth," to show how Jews are obsessed with the number six. ${ }^{89}$ Although Anderson does not reference other theocentric Christian conspiracists who write about Jews and the numerological meaning of "six," it lies in the backdrop of his analysis. Other theocentric Christian conspiracists who are Holocaust deniers discuss the supposed Jewish obsession with the number six, which they associate with Satan and carnality. ${ }^{90}$ The interpretation of hidden signs and symbols, especially satanic signs and symbols, forms a key part of many of Anderson's sermons and films on the end times. The idea of six being "like a magic number" ${ }^{91}$ rests on Anderson's persona as a religious authority; he appears to be unmasking hidden spiritual knowledge directly connected to definitive historical and scientific "evidence." Since, in his mind at least, "six million" is not based on "real history or science," Anderson emerges as the authority on the real history and real science behind the number's meaning. By injecting a deeper spiritual or prophetic meaning into "six million," Anderson asserts his interpretive authority over and above other Holocaust deniers. There is a sense in which "rationalist" Holocaust deniers found the evidence of "Jewish lies," yet they apparently do not realize the deeper spiritual dimensions of the "Holocaust myth."

The majority of the middle section of "Did the Holocaust Really Happen?" primarily raises easy to debunk pseudoscience and a profound misunderstanding of the Holocaust and WWII history.

\footnotetext{
${ }^{86}$ Anderson, Did the Holocaust Really Happen?, 00:02:40-00:03:05; juxtaposed to Holocaust deniers with neo-Nazi inclinations, Anderson has denigrated Hitler on several occasions, see Steven L. Anderson, "Hitler was NOT a Christian!," YouTube video, 14:04, uploaded December 28, 2017, accessed July 30, 2019, https://www.youtube.com/ watch? $\mathrm{v}=\mathrm{NjfoFRB}-\mathrm{qWW}$.

${ }^{87}$ James E. Young, The Texture of Memory: Holocaust Memorials and Meaning (New Haven: Yale University Press, 1993$), 141$.

${ }^{88}$ Anderson, Did the Holocaust Really Happen?, 00:05:40-00:06:50.

${ }^{89}$ Ibid., 00:06:02-00:06:27.

${ }^{90}$ Marrs emphasizes the spiritual significance of six as well, see Conspiracy of the Six-Pointed Star, loc. 313, 588, Kindle; also see recording of Texe Marrs' radio show, Power of Prophecy, where he discusses the Holocaust: Texe Marrs, "Texe Marrs-Holocaust Dogma Unmasked," Archive.org audio, 59:31, uploaded December 14, 2011, accessed February 15, 2020, https://archive.org/details/TexeMarrs-HolocaustDogmaUnmasked 979/TexeMarrs-HolocaustDogmaUnmaskedPart3.flv.mp3. On the Star of David as a satanic symbol, see Wittenberger, Marching to Zion, 00:41:30-00:43:47.

${ }^{91}$ Anderson, Did the Holocaust Really Happen?, 00:06:38-00:06:50.
} 
To reiterate, most of Anderson's "evidence" is primarily taken directly from the arguments of a prior generation of organized Holocaust deniers, and he does not necessarily illuminate spiritual truths at every turn. For example, he claims other death camps besides Auschwitz were simply labor camps, the gas chambers are fake, the number of bodies cremated was impossible, Zionists collaborated with the Nazis, survivors and eyewitnesses lie for monetary gain, etc. ${ }^{92}$ But, it should be noted that according to Anderson the "official version" of the Holocaust is as follows: "[the] story of the Holocaust is that the Jews were just rounded up and brought straight to a death camp and straight to their death." As evidence against the "official version," Anderson cites photos of the emaciated survivors, inquiring, "why would they look skinny and emaciated? It takes months to get that skinny and emaciated. You know, you don't get that way overnight." ${ }^{93}$ In Anderson's mind, since survivors were so emaciated they clearly were not rounded up and sent straight to the death camps, as the "official version" maintains. Like other Holocaust deniers, Anderson shows "a deep and abiding ignorance of the overwhelming majority of recent Holocaust research" and fights against "hallucinated debate partners." 94

After this middle section that centers on fairly standard pseudoscience in Holocaust denial, Anderson's video concludes by circling back to the spiritual implications of the "Holocaust hoax." The mass extermination of Jews in WWII is a lie "they" or "these people" tell. "They" or "these people" is intentionally vague, but Anderson is signaling "Jews," the synagogue of Satan and the ultimate liars in human history. According to Anderson, people should not be surprised that Jews would lie. He asserts this claim with another biblical prooftext, "the Bible says who is a liar but he that denieth that Jesus is the Christ," 95 and then elaborates, "why would it surprise you that the people who deny the Christ, they deny that Jesus is the Messiah, would lie to you about something else?" ${ }^{\prime 96}$ Anderson and similar theocentric Christian conspiracists who are Holocaust deniers often cite 1 John 2:22 when claiming that Jews are chief among liars. ${ }^{97}$ Engaging in the ultimate lie, i.e. denying Jesus as messiah, it is self-evident to Anderson that Jews would invent the Holocaust as well.

Like Marching to Zion, "Did the Holocaust Really Happen?" is not really intended for nonChristians or Jews. Once again, Anderson ultimately wants to convince Christian Zionists, who he often equates with dispensationalists, that they are theologically misguided and should oppose the State of Israel. Conversion is central to Anderson's attempt to debunk Christian Zionism. ${ }^{98}$ Because some Christian Zionists, most notably dispensationalist Christian Zionists, believe that Jews have a unique and ongoing relationship with God, they are sometimes hesitant to share the Christian message with Jews, which would, as Anderson understands it, save Jews from eternal damnation. In not sharing the Christian message of universal redemption exclusively through Jesus, such Christian Zionists have crossed a boundary into non-Christian territory.

Anderson did not invent the fear of Christian Zionism's boundary crossing out of thin air, and he is not alone in this fear. On the boundaries between Judaism and Christianity, Daniel Boyarin has noted, "the borders between Christianity and Judaism are as constructed and imposed, as artificial and political as any of the borders of the earth." ${ }^{99}$ Though Boyarin was referring primarily to the

\footnotetext{
${ }^{92}$ Anderson reveals one of his direct influences when he tells viewers to read Victor L. Thorn, The Holocaust Hoax Exposed: Debunking the 20th Century's Biggest Lie (Independent Publisher, 2012).

${ }^{93}$ Anderson, Did the Holocaust Really Happen?, 00:24:22-00:25:02.

${ }^{94}$ Terry, Holocaust Denial in the Age of Web 2.0, 43.

${ }^{95}$ Anderson, Did the Holocaust Really Happen?, 00:26:27-00:27:00; citing 1 John 2:22, KJV.

${ }^{96}$ Ibid., 00:26:27-00:27:00.

${ }^{97}$ Examples include Marrs, Conspiracy of the Six-Pointed Star, loc. 719, Kindle; Hendrie, Bloody Zion, loc. 259, Kindle; Hendrie, Solving the Mystery of Babylon the Great, loc. 4779, Kindle.

${ }_{98}$ Anti-dispensationalism and anti-Zionism are key components of the New IFB, see "What is the New IFB Movement?" As stated above, the New IFB appears to have fallen on hard times. The New IFB website disappeared in February 2020. My citation in the works cited includes a screen capture of the website dated December 11, 2019. Again, see Hatewatch Staff, In the Midst of Infighting, Anti-LGBTQ Church Network's Website and Social Media Disappear.

${ }^{99}$ Faydra L. Shapiro, "The Messiah and Rabbi Jesus: Policing the Jewish-Christian border in Christian Zionism," Culture and Religion 12, no. 4 (2011), 464, accessed July 10, 2019, doi: https://doi.org/10.1080/14755610.2011.633537. For the quote from Boyarin, see Daniel Boyarin, Border Lines: The Partition of Judaeo-Christianity (Philadelphia: University
} 
boundaries between Christianity and Judaism in antiquity, notable Christian communities and Christian movements in modern history occasionally challenge what appear to be rigid boundaries between Christianity and Judaism. Religious studies scholar Faydra L. Shapiro recently extended Boyarin's work to the contemporary relationship between Jews and Christians, suggesting that the boundaries between the two might be more flexible than most people assume, academics and nonacademics. Shapiro states that the "Jewish-Christian border - fence, if you prefer - is both still alive and still being undermined: scaled, dug under, peered through, gaped at and crossed over." ${ }^{\prime 100} \mathrm{~A}$ key example is the prominent dispensationalist and Christian Zionist John Hagee. Shapiro shows how Hagee was criticized by many evangelical Christians for apparently claiming that "Jews are saved through their own covenant with God," which signified he was possibly "denying the universal Messiahship of Jesus Christ."101 In the eyes of these evangelical Christians, Hagee had transgressed a boundary dividing Christianity from Judaism. Anderson, a strong critic of Hagee, tends to depict all dispensationalist Christian Zionists as following in the footsteps of Hagee. In reality, not all dispensationalists align with Hagee's view.

Anderson takes the notion of boundary crossing a step beyond most Christian critics of Hagee. According to Anderson, dispensationalist Christian Zionists have drifted toward a bastardization of Christianity that mirrors Judaism itself in seeking to establish a kingdom on earth, the State of Israel. In light of the cosmic dichotomy between Jews (carnal) and Christians (spiritual), Christians who support Israel are deviants from the true Christian path. While dispensationalist Christian Zionists might be to blame for boundary crossing, it was prominent Jews who supposedly realized that dispensationalism was advantageous to achieving their earthly kingdom. Anderson and Marrs believe a secret society filled with wealthy American Jews backed the modern popularizer of dispensationalism, Cyrus I. Scofield, underwriting the publication of his Scofield Reference Bible, which had a major impact on the growth of dispensationalism in the United States. ${ }^{102}$ Jews might not have necessarily invented dispensationalism, but Jews supposedly recognized that this theological view could secure their new material kingdom in Palestine. In other words, Jews used their conspiratorial machinations to "Judaize" Christianity through dispensationalism. ${ }^{103}$ Dispensationalist Christian Zionists in particular, therefore, need a course correction from a material focus to a spiritual one, which would sever their relationship with the State of Israel.

To convince fellow Christians of his position, Anderson attempts to put the Holocaust in an eternal perspective, very crassly one might add. Jews, he says, should fear, "The real Holocaust... the real burnt offering is going to be when all of these Jews who don't believe in Jesus Christ go to hell for eternity. That's the oven that they ought to be worried about." ${ }^{104}$ In seeking to convert Jews to Christianity, and thereby save them from damnation, Anderson claims he is actually loving Jews - "I don't hate Jews at all, I want them to be saved." 105 In Anderson's mind, if certain Christian Zionists believe God has a special relationship with Jews, whereby Jews do not need Jesus, then those Christian Zionists are the real antisemites. They hate Jews by allowing Jews to go to hell without hearing the Christian gospel. If a Christian really wants to hate a Jew, they should remain quiet when they have an opportunity to save a Jew's soul from hell. In "Did the Holocaust Really Happen?," Anderson emphasizes his "love" for Jews in contrast to his theological opponents: "If

of Pennsylvania Press, 2004), 1; also see Faydra L. Shapiro, Christian Zionism: Navigating the Jewish-Christian Border (Eugene: Cascade Books, 2015).

${ }^{100}$ Shapiro, The Messiah and Rabbi Jesus, 464.

${ }^{101}$ Ibid., 467.

${ }^{102}$ In Marching to Zion, Marrs said of Cyrus I. Scofield: "He had Jewish retainers who made him a member of the Lotus club - sort of a secret society - and suddenly he had plenty of money... With that amount of money, the [Scofield] Bible took off, and it basically sealed the deal for the Jews." From Faithful Word Baptist Church, Marching to Zion Full Movie Transcript.

${ }^{103}$ Marrs, Blood Covenant With Destiny, loc. 2296, Kindle; also see Anderson, Israel Moments 11-20.

${ }^{104}$ Anderson, Did the Holocaust Really Happen?, 00:28:20-00:28:45; also see Steven L. Anderson, "How to Hate a Jew," YouTube video, 4:04, uploaded October 2, 2017, accessed July 30, 2019, https://www.youtube.com/watch?v=jyOhrl lrIA. [Removed from YouTube as of August 2019]; Marrs and Framing the World, Texe Marrs Interviews Steven Anderson About 'Marching to Zion' Part 1, 00:18:49-00:19:08.

${ }^{105}$ Marrs and Framing the World, Texe Marrs Interviews Steven Anderson About 'Marching to Zion' Part 1, 00:18:49-00:19:08. 
you really love Jews, instead of talking about this myth of six million... why don't you worry about the real oven, which is the oven that God made-hell, and warn these Jews before they go to the burnt offering, before they go to hell... let's warn them about the satanic religion that they are wrapped up in, Judaism."106

In the backdrop of this statement is Anderson's emphasis on "soul-winning," a preoccupation shared by other New IFB pastors. The New IFB is a movement within the IFB that is explicitly anti-Zionist and anti-dispensationalist. For all intents and purposes, Anderson is the head of this movement. As Anderson describes soul-winning, it is a belief and a practice. It is a belief in the immediate necessity to save as many people from hell as possible, which in turn drives soul-winning practices, like soul-winning marathons, i.e. going door-to-door to bring lost souls to Christ. Anderson and other New IFB pastors travel around the United States to help one another's churches run soul-winning marathons. ${ }^{107}$ For Anderson, true love means being willing to win any and all souls.

In Anderson's eyes, the Holocaust is a myth that has collective or global impacts on soulwinning. That is, the impacts go beyond potentially stifling the individual Christian's willingness to convert Jews.

This lie of the Holocaust does a lot of damage to a lot of people, and let me tell you why, because Jewish children are brainwashed with this thing and they are taught this is what the Christians, even though Christianity obviously had nothing to do with it in the Third Reich, but that's what they will say... you know, Christianity has done this to you and they teach their children that Christians have murdered their ancestors and they've always hated and killed you and it culminated in the Holocaust and so they basically demonize Christians to these Jewish children. ${ }^{108}$

Here, Anderson states that the Holocaust keeps Jewish children at a distance from Christianity because Jews teach their children that Christians and Christianity were to blame for the Holocaust. Scholars who study the Holocaust have long noted historic connections between the genocide and the actions and inactions of Christian denominations, Christian laymen and laywomen, and Christian leaders, not to mention the role Christians played in fostering anti-Judaism and antisemitism more broadly. As quoted, Anderson says in the video that "Christianity obviously had nothing to do with it in the Third Reich." 109 Thus, though the Holocaust was a myth, Christianity is even further exonerated from anything and everything associated with Hitler and the Nazis. With this in mind, there is a sense in which the "Holocaust myth" is normal in history. Even though he denies the Holocaust took place, it functions as a means for Jews to frame Christianity as destructive. Elsewhere in films and sermons, Anderson subtly, though sometimes not so subtly, draws attention away from the historic role Christians have played in fostering anti-Judaism and antisemitism. For example, in Marching to Zion, Anderson never blames Christians for violence against Jews during the Middle Ages since, in his view, Jews were to blame for their blasphemy and "predatory lending practices."110 The "Holocaust hoax," akin to other ways Jews appear to demonize Christianity, must be reexamined and demolished for future generations of Jews to find their way to Jesus.

It is not only Jews who are negatively impacted by the "Holocaust myth" in Anderson's estimation. The Holocaust enabled Jews to acquire land in Palestine and became a factor in Christian

\footnotetext{
${ }^{106}$ Anderson, Did the Holocaust Really Happen?, 00:30:21-00:30:53; also see Anderson, Israel Moments 11-20.

${ }^{107}$ One just need search "soul-winning" on Anderson's blog: sanderson1611, Steven L. Anderson (blog), July 30, 2019, https://sanderson1611.blogspot.com/search/label/soul-winning; also see Steven L. Anderson, "A Strategy to Evangelize the Entire World 1: Exponential Soul-winning," Steven L. Anderson (blog), April 5, 2017, accessed July 30, 2019, https:// sanderson1611.blogspot.com/2017/04/but-he-that-received-seed-into-good.html.

${ }^{108}$ Anderson, Did the Holocaust Really Happen?, 00:33:21-00:33:53.

${ }^{109}$ Ibid., 00:33:29.

${ }^{110}$ Wittenberger, Marching to Zion, 00:32:18.
} 
Zionist support for Israel. ${ }^{111}$ Christian Zionists, influenced by international Jewry, continue to support an Israeli government that oppresses Palestinians. Because the American government has historically supported Israel, which is at odds with majority Muslim countries in the Middle East, geopolitical entanglements lead Muslims to associate Israel with the United States, which in turn causes them to conceptually link Isreal with its American Christian supporters. Therefore, Muslim hearts become hardened toward faith in Jesus by associating Christianity in general with Israel. Said more succinctly, Christian Zionists, influenced by Jews, stifle soul-winning among Muslims. Or, as Anderson summarizes, "fourteen million Jews and one billion Muslims are affected by this Holocaust hoax, and basically it affects how they view Christianity." 112 In other words, a significant portion of the world presently rejects Jesus because they have been presented a supposedly false image of Jesus, one influenced by Jewish leaders and supported, knowingly or unknowingly, by everyday Jews and Christian Zionists. According to Anderson, Jews-deniers of Jesus Christ and the ultimate liars in history - are responsible behind the scenes for the demonization of Christianity on a global scale. ${ }^{113}$

There is another layer to how supposed Jewish lies about the Holocaust negatively impact non-Jews. This time, the impact is felt at the societal or national level. It is certainly the case that a number of Christian Zionists affirm the idea that political support for Israel is pleasing to God and God will bless them in return. Such Christian Zionists often cite Genesis 12:1-3 as scriptural proof for the promise of God's return blessing when one blesses Israel, a passage in which God tells Abram (later, Abraham), "And I will bless them that bless thee, and curse him that curseth thee: and in thee shall all families of the earth be blessed."114 This approach to Israel taken by some American Christian Zionists has prompted one scholar to suggest that "Israel becomes a symbol of assent, a redemptive totem that provides a vicarious source of American redemption." 115 Anderson and his coterie assert the direct opposite of Christian Zionists on this point, which they address more thoroughly in Marching to Zion. The fact that America has been apparently sliding into greater moral decay is a sign God hasn't blessed America or American Christians for their ardent love of Israel. ${ }^{116}$ The extended implication is that Jews are perhaps one of the primary causes, if not the primary cause, of declining Christian morality in the United States. The "Holocaust myth," a tactic for garnering support for Israel, is a vital factor in the diminishing influence of Christianity in America. Christian Zionism, a form of "Judaized" Christianity, curses and condemns the very nation (America) it purports to bless. ${ }^{117}$

With this last point in mind, it is helpful to consider Gregory H. Stanton's understanding of denial in his now famous "Stages of Genocide." Stanton notes how genocide denial often involves both denying a genocide took place and blaming victims for whatever did occur (though not claimed to be a genocide). ${ }^{118}$ As a form of genocide denial, Holocaust denial commonly involves both tactics as well. Holocaust deniers will state that there was no genocide and then claim that whatever occurred was understandable or justified because Jews were traitors, Bolsheviks, internationalists, etc. Anderson, however, takes his denial into spiritual dimensions-supposed Jewish lies have eternal reverberations.

\section{Conclusion}

What will be the results of Steven Anderson's Holocaust denial? Why discuss Anderson's

\footnotetext{
${ }^{111}$ Anderson, Did the Holocaust Really Happen?, 00:31:30-00:32:20.

${ }^{112}$ Ibid., 00:34:40-00:34:55.

${ }^{113}$ Ibid.

${ }^{114}$ Genesis 12:3, KJV.

${ }^{115}$ Sean Durbin, “'I am an Israeli': Christian Zionism as American redemption," Culture and Religion 14, no. 3 (2013), 341, accessed July 10, 2019, doi: https://doi.org/10.1163/9789004385009 008.

${ }^{116}$ Wittenberger, Marching to Zion, 00:31:31-00:32:17.

${ }^{117}$ Anderson, Israel Moments, 11-20.

${ }^{118}$ Gregory H. Stanton, “The 10 Stages of Genocide," Genocide Watch, 1996, accessed July 30, 2019, https://www. genocidewatch.com/ten-stages-of-genocide.
} 
Holocaust denial at all? ${ }^{119}$ Anderson does not intersect prominent Christian circles and he is rigidly uncompromising in his theological views. It is presently unlikely, though not impossible, that his theologically-centered Holocaust denial will gain traction in broader Christian movements, denominations, organizations, or churches, let alone make headway into the wider American culture. However, the networks he intersects - the New IFB and theocentric Christian conspiracist communities-have been constructing a fairly robust infrastructure over the last decade. Both networks give Anderson an expanded platform as he seeks to influence a much larger section of the Christian populace. Will Christians run to Anderson's "loving" embrace? Probably not. Regardless, Anderson has perhaps made Holocaust denial more palatable for some believers. The bigger threat, however, is that with Holocaust denial cut loose from the figureheads and institutions of a prior generation of Holocaust deniers, Anderson and fellow antisemitic theocentric Christian conspiracists might open an avenue for spiritual arguments to become more widely accepted in Holocaust denier circles and among internet conspiracists. Particularly if the antisemitic theocentric Christian conspiracist infrastructure can continue expanding and adapting, and such conspiracist deniers can remain united by their family resemblances, they might become a significant group within Holocaust denial.

The spiritual significance Anderson gives Holocaust denial has already circled back into Holocaust denier spaces in some interesting ways. In the $\mathrm{CODOH}$ forum mentioned above, forum participants affirmed that Anderson is onto something in emphasizing the Jewish control of American Christianity. The aforementioned Rmbrmb21 wrote about a pastor at their church who holds to replacement theology but "still buys into the holocaust [sic]." In seeking to influence their own pastor and other Christian religious leaders, Rmbrmb21 then said, "Hopefully, we can reach more religious people in America. If you could convert half of American Christians to reject the holocaust [sic] as a fact, and embrace that it's a myth, you would be converting about $1 / 6$ th of the population." Rmbrmb21 continued their post by emphasizing the value of theology in Holocaust denial and the demonization of Jews, "I understand a lot of people will be very disinterested in reading about theology, it is important to our cause as Christianity is being excessively curbed in order to support the Jewish agenda." 120 Another regular contributor to the forum responded, "If this rotten situation is to be turned around, and this Holohoax is to be exposed, we need more people like Pastor Anderson in the Christian evangelical community who have the courage to look into the evidence and speak out about it." ${ }^{121}$ Anderson's Holocaust denial, therefore, returns to the already faithful and reenergizes them in new ways. They now have explicitly religious arguments and a religious advocate/"authority" for spreading Holocaust denial.

\section{Acknowledgements}

I would like to thank Dr. Eric Goldstein, Dr. William Allington, Dr. Deborah Lipstadt, Holocaust Denial on Trial (HDOT), and the Tam Institute for Jewish Studies at Emory University for their support and encouragement. I would also like to thank Dr. John Cox and the Center for Holocaust, Genocide, \& Human Rights Studies at the University of North Carolina at Charlotte for allowing me the opportunity to present a previous iteration of this paper at their 2019 conference "Denial: The Final Stage of Genocide."

\section{Bibliography}

Allington, William. "Holocaust Denial Online: The Rise of Pseudo-Academic Antisemitism on the Early Internet." Journal of Contemporary Antisemitism 1, no. 1 (2017), 33-54. Accessed July 15, 2019. Doi: $10.26613 /$ jca/1.1.4

American Jewish Committee. The Working Definition of Anti-Semitism: What Does It Mean, Why Is It

\footnotetext{
${ }^{119}$ I follow Allington in suggesting that, "it is important to determine how Holocaust denial is promoted, where it is promoted and how successful it is." See Allington, Holocaust Denial Online, 34.

${ }^{120}$ Rmbrmb21, July 2, 2017, 01:36 AM, comment on “Re: How Pastor Steven Anderson became a Holocaust Revisionist," CODOH Forum, accessed July 30, 2019, https://forum.codoh.com/viewtopic.php?t=11215.

${ }^{121}$ diaz52, July 2, 2017, 9:26 AM, comment on "Re: How Pastor Steven Anderson became a Holocaust Revisionist," CODOH Forum, accessed July 30, 2019, https://forum.codoh.com/viewtopic.php?t=11215.
} 
Important, and What Should We Do With It? American Jewish Committee, York. Accessed February 10, 2020. https://www.ohchr.org/Documents/Issues/Religion/Submissions/JBIAnnex1.pdf.

Anderson, Steven L. "A Strategy to Evangelize the Entire World 1: Exponential Soul-winning." Steven L. Anderson (blog). April 5, 2017. Accessed July 30, 2019. https://sanderson1611. blogspot.com/2017/04/but-he-that-received-seed-into-good.html.

. "Did the Holocaust Really Happen?" Archive.org video, 37:09, 2015. Accessed July 30, 2019. https://archive.org/details/PastorStevenAndersonDidTheHolocaustReallyHappen.

. "Hardball Interview with Pastor Steven Anderson." YouTube video, 1:03:12. Posted on June 29, 2017. Accessed July 30, 2019. https://www.youtube.com/watch?time continue $=280 \& v=S Y W U t 6 \mathrm{k}$ Eog.

. "Hitler was NOT a Christian!" YouTube video, 14:04. Uploaded December 28, 2017. Accessed July 30, 2019. https://www.youtube.com/watch?v=NjfoFRB-qWw.

. "How to Hate a Jew." YouTube video, 4:04. Uploaded October 2, 2017. Accessed July 30, 2019. https://www.youtube.com/watch? v=jyOhrl lrIA. [Removed from YouTube as of August 2019].

. “I'm North African!" Steven L. Anderson (blog). August 14, 2014. Accessed July 30, 2019. https://sanderson1611.blogspot.com/2014/08/im-north-african.html.

. "I Have Jewish DNA!" Steven L. Anderson (blog). September 2, 2014. Accessed July 30, 2019. https://sanderson1611.blogspot.com/2014/09/i-have-jewish-dna.html.

. "I'm Blacker than I Thought!" Steven L. Anderson (blog). September 3, 2014. Accessed July 30, 2019. https://sanderson1611.blogspot.com/2014/09/im-blacker-than-i-thought.html.

. "Israel Moments 11-20." Faithful Word Baptist Church, August 2014. Accessed May 13, 2019. http://www.faithfulwordbaptist.org/israel moments 11 20.html.

. "Live Phone Q\&A with Pastor Steven L Anderson (11/25/14 6:00pm)." YouTube video, 3:00:10. Uploaded November 25, 2014. Accessed July 30, 2019. https://www.youtube.com/ watch? $\mathrm{v}=\mathrm{aFh} \times \mathrm{XngZ2i8}$.

. "Muslim Hate and Pro-war Propaganda." Steven L. Anderson (blog). October 9, 2014. Accessed July 30, 2019. https://sanderson1611.blogspot.com/2014/10/muslim-hate-andpro-war-propaganda.html.

. "My Mom is Part Asian!" Steven L. Anderson (blog). September 4, 2014. Accessed July 30, 2019. https://sanderson1611.blogspot.com/2014/09/my-mom-is-part-asian.html.

. "My 92 Year-Old Grandma's DNA Results." Steven L. Anderson (blog). September 15, 2014. Accessed July 30, 2019. https://sanderson1611.blogspot.com/2014/09/my-92-year-oldgrandmas-dna-results.html.

--------. "New Documentary-Marching to Zion," Steven L. Anderson (blog). July 27, 2014. Accessed July 30, 2019. https://sanderson1611.blogspot.com/2014/07/new-documentarymarching-to-zion.html.

Ariel, Yaakov. "Israel in Contemporary Evangelical Christian Millennial Thought." Numen 59, no. 5/6 (2012), 456-485. Accessed July 1, 2019. Doi: 10.1163/15685276-12341235

-. An Unusual Relationship: Evangelical Christians and Jews. New York: New York University, 2013.

. "An Unexpected Alliance: Christian Zionism and its Historical Significance." Modern Judaism 26, issue 1 (2006), 74-100. Accessed July 10, 2019. Doi: $10.1093 / \mathrm{mj} / \mathrm{kjj} 005$

Barkun, Michael. A Culture of Conspiracy: Apocalyptic Visions in Contemporary America, 2nd ed. Berkeley: University of California Press, 2013.

---------. Religion and the Racist Right: The Origins of the Christian Identity Movement, revised edition. Chapel Hill: University of North Carolina Press, 1997.

BBC. "America's 'Hate' Preacher: Pastor Steven Anderson-BBC Documentary." YouTube video, 23:29. Accessed July 30, 2019. https://www.youtube.com/watch?v=K4PvxG2Kh4E.

Boston, Rob. "Pastor Of Hate: When Religious Right Rhetoric Goes Too Far." Wall of Separation (blog). Americans United for Separation of Church and State, September 2, 2009. Accessed March 1，2020. https://www.au.org/blogs/wall-of-separation/pastor-of-hate-when- 
religious-right-rhetoric-goes-too-far.

Boyarin, Daniel. Border Lines: The Partition of Judaeo-Christianity. Philadelphia: University of Pennsylvania Press, 2004.

Byford, Jovan. Conspiracy Theories: A Critical Introduction. New York: Palgrave Macmillan, 2011.

Christian, Peter. Lucifer's Army: An Exposé of Talmudic Tyranny. Barnes Review, 2017.

-------. One Nation Under Zion: Zionist Influence on America. Barnes Review, 2013.

. The Work of All Ages: The Ongoing Plot to Rule the World from Biblical Times to the Present. Barnes Review, 2010.

Collins English Dictionary, s.v. "Theocentric." Accessed March 1, 2020, https://www. collinsdictionary.com/us/dictionary/english/theocentric.

deHaven-Smith, Lance. Conspiracy Theory in America. Austin: University of Texas Press, 2013.

Dignity Memorial. “Obituary: Texe Marrs, July 15, 1944-November 23, 2019.” Dignity Memorial. Accessed August 5, 2020. https://www.dignitymemorial.com/obituaries/austin-tx/texemarrs-8938309.

Durbin, Sean. "'I am an Israeli': Christian Zionism as American Redemption." Culture and Religion 14, no. 3 (2013), 324-347. Accessed July 10, 2019. Doi: 10.1163/9789004385009 008

Faithful Word Baptist Church. "'Marching to Zion' Full Movie Transcript." May 14, 2015. Accessed August 1, 2019. https://www.faithfulwordbaptist.org/m2z full english.html.

Fowler, Lilly. "Praying for Obama's death." Salon, November 24, 2009. Accessed July 30, 2019. https://www.salon.com/2009/11/24/praying for obama death/.

Framing the World. "Framing the World Store." Accessed July 30, 2019. https://framingtheworld. com/store/ols/categories/dvds.

Goldman, Samuel. God's Country: Christian Zionism in America. Philadelphia: University of Pennsylvania Press, 2018.

Haaretz. "US Pastor Dupes Rabbis into Anti-Semitic Film." Haaretz, January 1, 2015. Accessed July 30, 2019. https://www.haaretz.com/jewish/u-s-pastor-dupes-rabbis-into-anti-semiticfilm-1.5346628.

Hatewatch Staff. "In the Midst of Infighting, Anti-LGBTQ Church Network's Website and Social Media Disappear." Hatewatch (blog). Southern Poverty Law Center. February 21, 2020. Accessed April 15, 2020. https://www.splcenter.org/hatewatch/2020/02/21/midstinfighting-anti-lgbtq-church-networks-website-and-social-media-disappear.

Hendrie, Edward. Bloody Zion: Refuting the Jewish Fables That Sustain Israel's War Against God and Man. Great Mountain Publishing, 2012. Kindle.

---------. Solving the Mystery of Babylon the Great: Tracking the Beast from the Synagogue to the Vatican, 2nd ed. Great Mountain Publishing, 2012. Kindle.

Hoffman, Michael. Judaism Discovered: A Study of the Anti-Biblical Religion of Racism, Self-Worship, Superstition and Deceit, 3rd ed. Independent History \& Research Co, 2008.

--------. Judaism's Strange Gods, 2nd ed. Independent History \& Research Co, 2000.

Kacala, Alexander. "Anti-gay Pastor Resigns After Allegedly ‘Being with Prostitutes'." NBC News, January 7, 2019. Accessed July 30, 2019. https://www.nbcnews.com/feature/nbc-out/antigay-pastor-resigns-after-allegedly-being-prostitutes-n955926.

Kaell, Hillary. Walking Where Jesus Walked: American Christians and Holy Land Pilgrimage. New York: New York University, 2014.

Lipstadt, Deborah. Denying the Holocaust, Denying the Holocaust: The Growing Assault on Truth and Memory. New York: Free Press, 1993.

-. "Holocaust Denial: An Antisemitic Fantasy." Modern Judaism 40, no. 1 (2020), 71-86. Accessed March 1, 2020. Doi: 10.1093/mj/kjz019 
. "The Trump Administration's Flirtation With Holocaust Denial." The Atlantic, January 30, 2017. Accessed March 1, 2020. https://www.theatlantic.com/politics/archive/2017/01/thetrump-administrations-softcore-holocaust-denial/514974/.

Livingston, Hannah. "'Hell's Gonna be Pretty Hot for You': My Summer with a Christian Hate Preacher." BBC, July 24, 2017. Accessed July 30, 2019. https://www.bbc.co.uk/bbcthree/ article/2e465c60-cdd3-48f5-8944-e9b2786e3ce9.

Marrs, Texe. Blood Covenant With Destiny: The Babylonian Talmud, the Jewish Kabbalah, and the Power of Prophecy. Austin: RiverCrest Publishing, 2018. Kindle.

---------. Conspiracy of the Six-Pointed Star: Eye-Opening Revelations and Forbidden Knowledge About Israel, the Jews, Zionism, and the Rothschilds. Austin: RiverCrest Publishing, 2011. Kindle.

. DNA Science and the Jewish Bloodline. Austin: RiverCrest Publishing, 2013. Kindle.

. Feast of the Beast. Austin: RiverCrest Publishing, 2017. Kindle.

. Holy Serpent of the Jews: The Rabbis' Secret Plan for Satan to Crush Their Enemies and Vault the Jews to Global Dominion. Austin: RiverCrest Publishing, 2016.

---------. “Texe Marrs-Holocaust Dogma Unmasked." Archive.org audio, 59:31. Uploaded December 14, 2011. Accessed February 15, 2020. https://archive.org/details/TexeMarrsHolocaustDogmaUnmasked 979/TexeMarrs-HolocaustDogmaUnmasked-Part3.flv.mp3.

Marrs, Texe, and Framing the World. "Texe Marrs Interviews Steven Anderson About 'Marching to Zion' Part 1." Interview by Texe Marrs, May 5, 2015. YouTube video, 1:03:12. Accessed July 30, 2019. https://www.youtube.com/watch?v=8vbUkXm8K3g.

---------. “Texe Marrs Interviews Steven Anderson About 'Marching to Zion' Part 2," YouTube video, 1:02:46. Uploaded May 6, 2016. Accessed July 30, 2019. https://www.youtube.com/ watch?v=3HaBBRsHTOY.

Martineau, Paris. "YouTube is Banning Extremist Videos. Will it Work?" Wired, June 5, 2019. Accessed July 30, 2019. https://www.wired.com/story/how-effective-youtube-latest-banextremism/.

Neiwert, David. "Arizona Pastor Boasts about Tricking Rabbis into Participating in Anti-Semitic Film." Hatewatch (blog). Southern Poverty Law Center, December 12, 2014. Accessed May 18, 2020. https://www.splcenter.org/hatewatch/2014/12/12/arizona-pastor-boasts-abouttricking-rabbis-participating-anti-semitic-film.

Norwood, Stephen H. "Convergent Anti-Zionisms: The American Far Left and Far Right." In Anti-Judaism, Antisemitism, and Delegitimizing Israel. Edited by Robert S. Wistrich, 119-134. Lincoln: University of Nebraska Press, 2016.

Robertson, David G. "Conspiracy Theories and the Study of Alternative and Emergent Religions." Nova Religio 19, no. 2 (2015), 5-16. Accessed July 1, 2019. Doi: 10.1525/nr.2015.19.2.5

Shapiro, Faydra L. Christian Zionism: Navigating the Jewish-Christian Border. Eugene: Cascade Books, 2015.

---------. "The Messiah and Rabbi Jesus: Policing the Jewish-Christian border in Christian Zionism." Culture and Religion 12, no. 4 (2011), 463-477. Accessed July 10, 2019. Doi: $10.1080 / 14755610.2011 .633537$.

Shermer, Michael and Alex Grobman, Denying History: Who Says the Holocaust Never Happened and Why Do They Say It? Berkeley: University of California Press, 2009.

Smith, Sarah. "Hundreds of Sex Abuse Allegations Found in Fundamental Baptist Churches Across U.S." Fort Worth Star-Telegram, December 9, 2018. Accessed July 30, 2019. https://www.startelegram.com/living/religion/article222576310.html.

Spector, Stephen. Evangelicals and Israel: The Story of American Christian Zionism. Oxford: Oxford University Press, 2009.

Stanton, Gregory H. "The 10 Stages of Genocide," Genocide Watch. 1996. Accessed May 1, 2020, https://www.genocidewatch.com/ten-stages-of-genocide.

Sweetnam, Mark S. "Defining Dispensationalism: A Cultural Studies Perspective." Journal of Religious History 34, no. 2 (2010), 191-212. Accessed July 20, 2019. Doi: 10.1111/j.1467$\underline{9809.2010 .00862 . x}$ 
Terry, Nicholas. "Holocaust Denial in the Age of Web 2.0: Negationist Discourse Since the IrvingLipstadt Trial." In Holocaust and Genocide Denial: A Contextual Perspective, edited by Paul Behrens, Nicholas Terry, and Olaf Jensen, 34-54. New York: Routledge, 2017.

The New Independent Fundamental Baptist Movement. "What is the New IFB Movement?" Accessed July 30, 2019. https://web.archive.org/web/20191211161128/https://www. thenewifb.com/what-is-the-new-ifb.

Thorn, Victor L. The Holocaust Hoax Exposed: Debunking the 20th Century's Biggest Lie. Independent Publisher, 2012.

Truth in Genesis. "The Jews and Their Lies Part 1 of 2." YouTube video, 1:04:11. Uploaded July 5, 2015. Accessed July 30, 2019. https://www.youtube.com/watch?v=ml-x4VaEaK0. . "The Jews and Their Lies Part 2 of 2." YouTube video, 1:05:43. Uploaded July 12, 2015. Accessed July 30, 2019. https://www.youtube.com/watch?v=MYrQXn9IUlM\&t=3073s.

USA Today. "Pastor defends his anti-homosexual sermon." Posted on December 6, 2014, YouTube video, 5:33. Accessed July 30, 2019. https://www.youtube.com/watch?v=UbSM kxpObc.

Westbrook, Matt. "Broadcasting Jesus' Return: Televangelism and the Appropriation of Israel Through Israeli-Granted Broadcasting Rights." In Comprehending Christian Zionism: Perspectives in Comparison, edited by Göran Gunner and Robert O. Smith, 61-83. Minneapolis: Fortress Press, 2014.

Wittenberger, Paul, dir. Babylon USA. 2017; Phoenix, AZ: Framing The World Productions, 2017. 94 mins. Accessed Aug 6, 2020. https://archive.org/details/BabylonUSA.

------. Marching to Zion. Phoenix, AZ: Framing The World Productions, 2015. 101 mins. Accessed July 30, 2019. https://archive.org/details/PastorStevenAndersonMarchingToZion.

---------. New World Order Bible Versions. Phoenix, AZ: Framing The World Productions, 2014. 99 mins. Accessed July 30, 2019. https://archive.org/details/ NewWorldOrderBibleVersionsFullMovie720.

Young, James E. The Texture of Memory: Holocaust Memorials and Meaning. New Haven: Yale University Press, 1993.

YouTube. "New IFB Documentaries." YouTube Channel. Accessed May 18, 2020. https://www. youtube.com/channel/UCN5OBnOh1-QGZ1sQqOxflbg/videos. 